\title{
Review of the Waqf and trust commission (WTC) in Zanzibar
}

\section{Issa Haji Ziddy}

Prof. Dr. State University of Zanzibar

\begin{abstract}
The Government of Zanzibar has prepared development strategies of Vision 2020 on a medium scale known as the Zanzibar Strategies for Growth and Reduction of Poverty (MKUZA II) whose main objectives are to take care of the economic growth and the reduction of poverty in Zanzibar. To streamline efficient service delivery to the beneficiaries in Zanzibar, the Government has placed religious duties and responsibilities to three Government-run institutions. These are the Kadhi's Court, the Office of the Mufti of Zanzibar and the Waqf and Trust Commission (WTC). Being allocated on a very strategic position commercially, politically and even socially, Zanzibar is sandwiched between several forces as shown in its history. In view of the aforesaid, there is a need to revisit the overall responsibilities of the three institutions, compare them with the capacity they have in reflection to both local environmental changes as well as those from a global perspective. This study will concentrate on reviewing the WTC, which is a corporate body that has the power to conduct, coordinate or regulate by using its name any of its functions in accordance with the provisions of the Act, Islamic law and rules of good practice. The aim is to review economic variables and functions of the WTC in relation to $95 \%$ of the population of Zanzibar. The study also is intended to explore the types of challenges facing the administration of the Waqf Commission in the areas of creativity, innovation, responsibility, involvement, support and participation of the concerned stakeholders and record management system.
\end{abstract}

\section{Keywords:}

Waqf, Waqf and Trust Commission, Islamic law, Shariah compliant 


\section{Introduction}

Zanzibar is an archipelago consisting of the two main islands of Unguja and Pemba and other surrounding small islets located in the Indian Ocean about $35 \mathrm{~km}$ off the coast of mainland Tanzania at a longitude of 39 degrees east and a latitude of 6 degrees south of the Equator. Since 1964, Zanzibar and Tanganyika together form the United Republic of Tanzania.

Figure 1: Location of Zanzibar, Unguja Island \& Pemba Island.

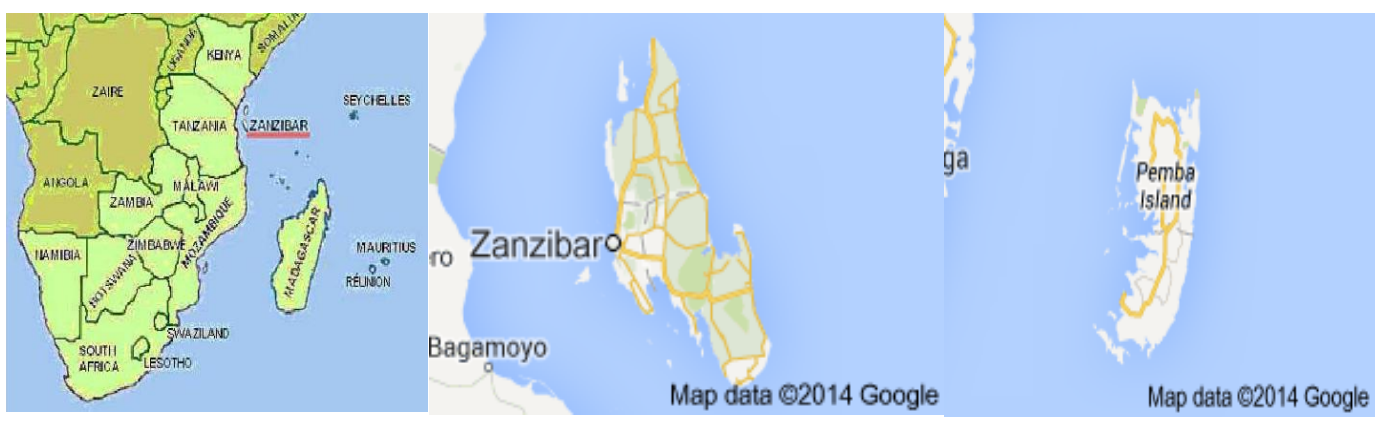

Source: https://www.zanzibar-paradise.com

The majority of Zanzibar people is Muslim, a fact reflected in Zanzibari lifestyle and culture. However, there are also Christian churches and Hindu temples which offer regular daily or Sunday services. The climate of Zanzibar is warm all year, 28-38 degrees Celsius, with cool sea breezes in the hottest months. Zanzibar is surrounded by coral reefs and there are miles of unspoiled white beach. A World Heritage site - and an old town called Stone Town, today is Zanzibar's capital city which is embracing the famous sheltered harbor that was once the busiest base for trade with the other parts of the world.

Figure 2 : Pictures from Zanzibar

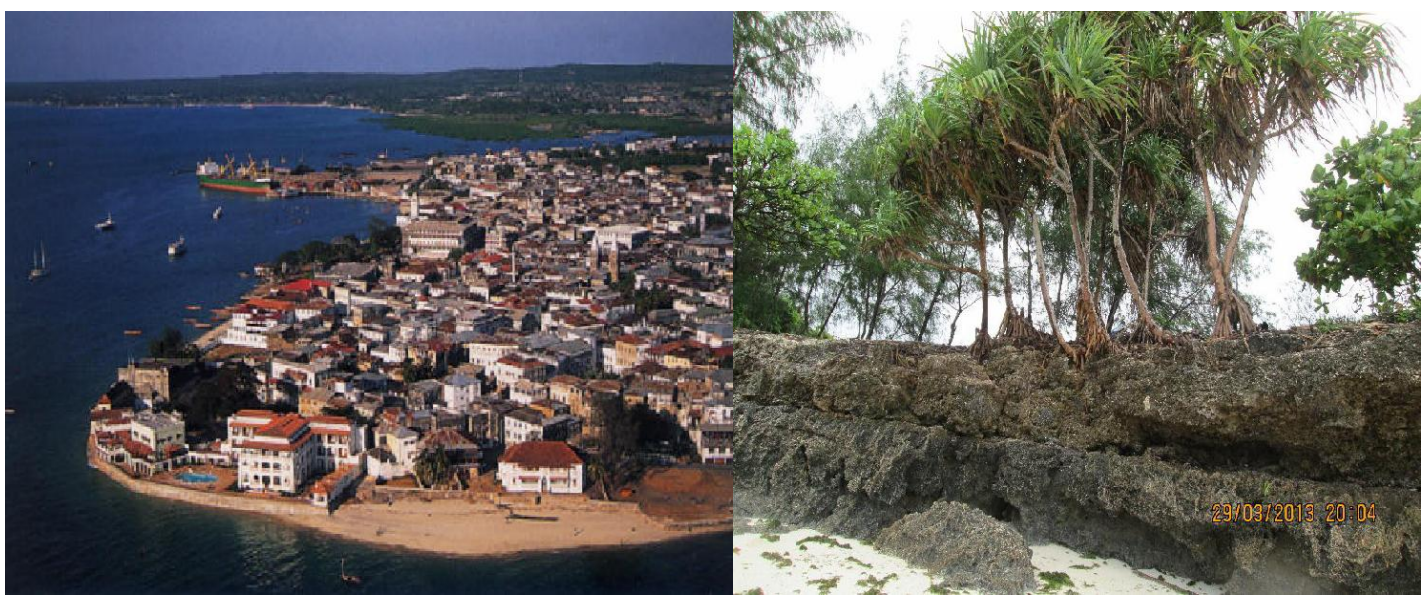


The history of Waqf in Zanzibar is as old as the establishment of Islam in the Zanzibar Islands. Muslims used to build Mosques and Zawiyas, bought land and declared awqaf's as discovered in the case of Kizimkazi Mosque (1107 AD). In 1830, Sheikh Nasser bin Khelef created a Waqf of lands which is now the town of Chake Chake in Pemba Island. The records of the Waqf Commission in Zanzibar show that a number of town houses and farms in the rural areas had been dedicated for the benefit of "the poor in Mecca and Medina" (Anne K. Bang, 2002).

During this early period of Waqf history, the management of awqaf was under the waqif (dedicator) or the Mutawallis (guardians) appointed by the waqif. Many Waqf deeds of that period show that this was the notable characteristic of Waqf management during the direct administration of Zanzibar Sultans (1832 - 1890).

At the beginning, the purposes of Waqf were influenced by the needs of the community, i.e. the administration of mosques, Islamic education and neighborhood welfare. This shows that the Waqf was well known in Zanzibar as an institution of the Islamic Shariah which allows for the dedication of property in support of welfare, well being and charitable objects of the community, such as the upkeep of mosques, payment of their officers, provision of graveyards, feeding of the poor, teaching, training and empowerment. In the other words Waqf may take the form of social - religious assets like schools, madrasas, clinics and masjids or may take the form of investments like shops, rent houses, industry and cultural halls where the capital investment is utilized to generate sustainable communities, social development projects or programs that benefit Muslims and other needy people in the broader community. The Waqf is, therefore, the only kind of long-term trust which Islamic Law permits (Abdul Sheriff, 1995). 


\section{REVIEW OF THE WAQF AND TRUST COMMISSION (WTC) IN ZANZIBAR}

\subsection{Waqf and Trust Commission (WTC) in Zanzibar}

The Waqf and Trust Commission in Zanzibar was officially established by the British Colonial Authorities in 1905 and laid down policies that would ensure control over the inheritance and all Waqf properties donated or dedicated by Muslims. Its powers were formalized in the so-called Waqf Property Decree of 1907. The Decree was formulated to grant the colonial authorities maximum control of Waqf properties and revenues. Failure to notify the Commission of a new or old Waqf - as well as any transaction relating to a Waqf property - was considered to be an offense.

From 1907 to 1963 the British made laws that ensured their full control over the Waqf Commission. The Awqaf Laws gave the British Resident in Zanzibar the mandate of nominating Waqf Commissioners before the Sultan, who ceremonially appointed them. During the colonial period, WTC consisted of four British officers as well as one Sunni and one Ibadi Qad'i. For the period from 1905 to 1925 , Ahmad b. Sumayt served as the Sunni representative. He was replaced by Tahir al-Amawi, who held the same position until 1936. He, in turn, was replaced by Ibn Sumayt's son Umar bin Sumayt, who served as Waqf Commissioner till the end of colonial rule in Zanzibar in 1963. Among the interesting feature of the WTC in this period is that there were trans-oceanic connections of Waqf between Zanzibar and other Islamic countries and cities, especially, Mecca, Oman, Madina and Turkey (Anne K. Bang, 2002).

The Revolutionary Government of Zanzibar that came to power on 12th January 1964, took control of all Waqf properties in the early days of the revolution and put them under the Administrator General's Office. This period witnessed the subsequent mismanagement and the collapse of a number of Waqf assets and records. The government issued decrees that nationalized several fertile Waqf plantations and some buildings. All Waqifs were forced to accept the guardianship of the Waqf Commission, which centralized the income of the Waqf properties.

In its administrative development of Waqf, Zanzibar has passed through several changes. During the revolutionary administration, 
some interesting decisions took place, which include amendment of Section 3 of the 1980 Decree (in 2001) that made the Mufti of Zanzibar the Chairperson of the WTC.

In January 2007, the WTC Governing Board was re- constituted by Act number 2 (of 2007). It is now a corporate body with power to conduct, coordinate or regulate by using its name any of its functions in accordance with the provisions of the Act, Islamic laws, rules and good deeds. It is also capable of acquiring, purchasing and alienating or disposing any property, movable or immovable and of entering into contracts for any of the purposes for which is capable (Mohammed H. Khalfan, 2009).

\subsection{Service Delivered by Current WTC}

The WTC is targeting a number of groups in delivering its services including Muslims who are legally involved in affairs such as inheritance and Waqf beneficiaries. Furthermore, the WTC has responsibilities with respect to the sensitive issue of trustee properties which usually belonged to orphans. Among the responsibilities of WTC is to hand over these properties once the owners become mature enough to take care of their own properties.

The WTC commonly works closely with internal and external stakeholders through a number of ways. It uses existing information channels to reach other stakeholders inside and outside the WTC including television, radio, newspapers and other information related tools. For example, through Zanzibar State television and radio, the WTC announces information regarding inheritance cases every week.

\subsection{Governance of WTC in Zanzibar}

Legal Status - talk about the acts, which originally put up the WTC and its major parts which include functions that are currently being directed by the office of Mufti. It also discusses the issues that made the government dismantle the office of Mufti from the WTC as it talks about the performance of the WTC in this period up to the time when it was seen that the parent legislation was changed (Act No. 2 of 2007)

The re-establishment of the WTC by Decree no. 5 of 1980 was 
taking place and the new Commission aimed at managing issues of Islamic affairs which had been centralized by the government since 1964. However, the way of governing the WTC as we have it today was not easy; it has been enacted, re - enacted and repealed as it appeared in Waqf Decree no. 2 of 1905, New Waqf Decree no. 2 of 1907, Waqf Decree no. 15 of 1909 (amendment), Waqf Property Decree no. 16 of 1916 which has changed the structure of the Commission through which the number of commissioners has been raised to eight including the Treasurer, the Provincial Commissioner, the Administrative General, the Assistant Administrator General and four other Islamic scholars who were appointed by the Sultan (Laws of Zanzibar 1934). Waqf Validating Decree no. 5 of 1946, Waqf Validating Decree no. 6 of 1951(amendment), Waqf Property Decree of 1959 Cap. 103 of the Laws of Zanzibar, Waqf Property Decree 1965 (amendment), Presidential Decree no. 12 of 1965, Presidential Decree no. 12 of 1966, Waqf Property Decree no. 7 of 1967 which repealed many provisions of the Waqf Property Decree and provisions of the Public Trustee Decree, Cap. 24, Administration of Waqf and Trust Property Decree no. 5 of 1980. Section 3 of the 1980 Decree was amended in 2001 and made the Mufti of Zanzibar the Chairperson of the Waqf Commission instead of Chief Kadhi.

\subsection{Leadership Composition of WTC}

The current WTC has a managing Board, Chief Executive Officer, a Pemba office and eight sections. Each of the core functions of the WTC is rather large which needs expertise and proper monitoring. The WTC sometimes resembles a court, a resource and educational center, an empowering agent, a coordinator and so forth. Its work routine is predictable on the basis of a monthly report for everyone, a monthly meeting of head of sections and a quarterly meeting of the Board and Implementation Coordinating Unity. To improve the proper working environment in the WTC and to increase productivity, the Management Board, executive personnel and staff should have the necessary skills, competencies, and commitment to pursue the objectives of the WTC.

The Executive Secretary is equivalent to the Deputy Secretary of the Ministry. Being an independent body having perpetual succession, a common seal and in its registered name, it is capable of suing and being sued; the Executive Secretary thus has to take a 
national and Islamic oath before the commencement of the office. Also, the WTC is capable of acquiring, purchasing and alienating or disposing any property, movable or immovable and of entering into contracts for any of the purposes. Although the review observed that the WTC has a good recording system, flexible internal working environment, it was realized that there is a deterioration observable of public work ethics, as well as instances of corruption and misuse of resources.

To improve these bad habits, there should be a committed and passionate leadership who has the necessary vision to guide and give direction to the organization. The mission of the WTC should be transmitted regularly through workshops, seminars, presentations, website, etc. There is also an immediate need for the management to pay special intention in combating and preventing corruption and misuse of resources of WTC. In this age where fraud and corruption is widespread in the corporate world, good corporate governance has become a sine qua non in business

\subsection{Administrative Practices of the Current WTC}

The main functions of the administrators of WTC are as follows:

- To administer Waqf Property, Trust - Property and the estates of deceased Muslims.

- To coordinate Hajj activities regarding pilgrims from Zanzibar and to supervise both individuals and organizations that are providing travel and other services to pilgrims.

- To coordinate and regulate the provision, collection and distribution of Zakat and other charitable gifts, provisions and offerings for religious purposes.

- To coordinate National Id prayers and the id Baraza, which are national religious festival days.

The mentioned functions led the WTC to have a structure that consists of three departments as follows:

i- Islamic Affairs Department which deals with awqaf, trusts and probates;

ii- Finance \& Administration Department that is dealing with the establishment, accounts, planning, and estates;

iii- The head office in Pemba Island.

The review shows that this structure is not flexible and does not facilitate the effective discharge of the office's functions as visu- 
alized under section 13 of the establishing Act. For instance, the enforcement, compliance and legal matters appear to have been minimized. There is therefore an urgent need for the review of the Commission's organizational structure.

However, the WTC structure has a large number of components with a large workforce; some of them work periodically, for example the Hajj committee which works in every year. Furthermore, the structure lacks a research and development (R\&D) section, which has undertaken several studies for the improvement of the Commission. The annual plan of the WTC is not quality as it only considers the service rather than production and income generation. Research projects should be undertaken to determine and document the status of Zanzibar Waqf properties and how to develop and improve them.

\subsection{Finance and Financial sources of WTC}

The funds and sources of the WTC consist of fees and charges collected by the Commission. All payments or property due to the WTC in respect of any matter is incidental to its functions; the WTC also receives grants, donations, bequests, or other contributions made to the WTC by any individual, farm, or the Government. However, these sources do not bring in sufficient financial resources for the WTC to fund all its undertakings. Even the subsidy received from the Government, through the national budget, is not adequate to bridge financial gaps, especially in the context of the ever increasing maintenance costs of Waqf properties most of which are situated in the Stone Town, often in bad condition and dilapidated. For example, in the financial year of 2011-2012, the WTC was authorized to receive a total amount of USD 187,500\$. But until March 2012 the amount deposited was USD 175,987.394\$ only. Among that amount USD 100,114.211\$ (approximately 57\%) was used to pay workers' salaries and 75,466,932\$ (approximately 43\%) was used for other expenses (Government of Zanzibar, Budget Speech 2011-2012).

The head office in Pemba has not been receiving sufficient disbursements to cater for its monthly operational financial requirements at all. For instance, the office has not received full salary requirements since October 2011. For the financial years of 20112012 the office was authorized the amount of USD 176,468.75\$ of the local works where $113,861.25 \$$ for workers' salaries and other 
allowances and USD 62,607,5\$ for other expenses. But until March 2012 the amount of USD 105,607.77\$ was deposited where USD $69,133,23 \$$ (approximately 61\%) was used for salaries and other expenses while the remaining percentage was used for other expenses. In order to bridge times when the WTC needs more funding when compared with what it actually gets annually, there is a need to find alternatives that will support its funding. This may be possible when the following measures could be taken care of:

Initial and ongoing funding for the Operational Capacity of the WTC should be supported by initial donations either as Operational funding grants or as an Operational Capacity Waqf. As the WTC grows and Waqf and Zakat funds and assets start pouring into its coffers, a clear policy on investments should be made. Careful thought should be given to how public, families and the NGO wishes to place itself. The Waqf Institution could become a mega trust body managing the Waqfs of thousands of waqifoon - public, private, organizational, institutional, family etc. or it could be selective. Various segments of the donor market need to be targeted with appropriately devised strategies and products.

In general, the disparity of salaries in the WTC is only due to the level of education of an employee and his position in the seniority system. In some cases the same level of education may lead to deferment in salary when the serving period in the WTC has been considered. The amount of salary for the workers of the WTC, thus ranged between TSHs 136,000 (85\$) for those who have the Primary education to TSHs 573, 000 (358.125\$) for the Master level of education.

The WTC currently has a plan to move away from dependence on government, financial support and plans to establish various investments through their properties. In some cases the WTC should, however, continue to rely on governed policy which made it depend only on services rather than business. The WTC also has plans to improve services and, where possible, to reach out to remote villages to advertise such services. The financial income from customers will therefore increase, according to national and global market, but this will depend on how they take responsibility to keep their assets in good condition.

Being an Islamic based institution, WTC will need the help and support of Shariah advisors. Going further, Shariah auditors will be needed to ensure compliance in the fields of investments and correct application of funds. Shariah compliance could be regarded 
as both a driver and a critical factor for success.

There is also a need to expand the WTC's financial resources by conducting feasibility studies of its properties and to mobilize people to use the services of the WTC in order to increase its income. The current situation needs to be supported by campaigns, through education, the mobilization of support and a variety of strategies that may be used to ensure success of the general revitalization and marketing strategy.

\subsection{WTC and Planning}

Development planning is an important asset for the development of the WTC. This includes long and short term planning. Unfortunately, the WTC is not good in planning and programming and this is probably due to financial constraints which allowed to achieve only minor targets. However, data show that the WTC has played an important role in midterm planning, while lacking a long term plan. For the financial year of 2012-2013, the WTC, for instance, planned to achieve the following targets:

- $\quad$ Proceeding in strengthening collection and distribution of alms and charity;

- $\quad$ Proceeding in the proper mode of supervising of Waqf's and trustee properties;

- $\quad$ Strengthening mode of service provision;

- Coordinate and supervising implementation of Ministerial affairs, including services provided by local organizations;

- Improvement of working environment and train Ministerial workers in Pemba office.

The review observed that the targets were not archived as expected. This means that good planning is not only the guarantee of success. It also needs other resources, including human, financial and material resources.

\subsection{WTC and Human Resources}

The WTC lacks experience and qualified staff. According to the above mentioned review, the WTC's structure requires personnel and expertise in civil engineering as necessary for the upkeep of the quality of its buildings and the re-construction and repairing of existing houses. Neither, does it have IT nor IEC experts. This may be resolved by training existing staff, initiating the regular staff 
appraisal system and by recruiting competent manpower. There is an urgent need of recruiting a civil engineer and IT personnel in Unguja and Pemba that will initiate the establishment of a computerized central database and the website. These are important tools for today's successful organizations.

Another difficulty is that there are shortcomings regarding several specializations of Waqf. Education of most of the available staff is secondary school or below. They execute jobs assigned to them through experience and are not easily trainable. However, in order to improve the status, performance and development of the WTC, the management should prepare a number of trainings and lessons for their internal and external staff.

The work of the WTC is organised according to the chain of administration level as there is a direct connection between each level of staff vertically and horizontally. For example, the Executive Director of the WTC should submit an issue directly to the Ministry of Constitutional Affairs but he should contact the Principal Secretary before the implementation.

According to an interview with the Executive Director of the WTC, the process of monitoring and evaluation within the WTC is done almost every month. The individual officer after doing an assessment of the monthly task and the head of each department submit a report about their respective tasks to the monthly meeting of all heads of departments. The WTC has an officer in charge to follow up the working responsibilities of every department of the WTC. This activity aims at examining the performance of WTC and creates a beneficial environment of working, while at the same time enabling proper accountability of the individual worker, office, departments and WTC as a whole.

To improve work further, there must be coordination between the executive secretary and each head of section. It is proposed that the heads of sections in Islamic i.e Waqf, Probate and Islamic Affairs should be Head of Islamic Division/ directorate, while Head of one of the Supporting Section should be Head of the Administration and Finance. The head of Pemba Office must also be included at this level with two sections. The term of these offices must be three renewable years. The Executive Secretary should be vested with the power of appointment. 


\subsection{Relationship between the WTC, Public and other Local and International Institutions}

The WTC does not work in isolation; it has good relations with the civil society within and outside of Zanzibar. It also works closely with other religious institutions, local governments, registrar offices, the courts, Stone town authority and so forth in its everyday responsibilities. This has led to comparatively wide support from stakeholders in the WTC's initiatives. However, some members of the Zanzibar community have a very small and distorted knowledge of the WTC's functions. Historically, the community used to have a negative perception towards its responsibilities due to the deterioration of religious values among both stakeholders and some members of staff. Therefore, there is a need to have a proper transparent coordinating mechanism and regular meetings with stakeholders for regular considering of its common issues. The stakeholders of each Waqf institution need to be identified. Clearly the Muslim Community as a whole, the beneficiaries, and Mutawallees are major stakeholders and the Waqf Institution will need its support. The Muslim Ummah and particular segments of it are also the target market to 'sell' the Waqf Institution's Waqf Product. The assumption of community ownership of the WTC would be important in this situation, as they become supporters and protectors of their organization. Just like a business that is family owned where each member will ensure that the business succeeds for if it succeeds everyone succeeds and if it fails, everyone fails.

On the other side, the review observed that, although there are some local bodies, communities and organizations that administer their Waqf assets in Zanzibar, the Act number 2 of 2007 is very clear on the need of centralization of the Waqf administration. Even though,

Inquipy

2015/1 mutual relationships may be sustained if WTC will see the importance of delegating these institutions some of the administrative work. But it must make sure that it centralizes registers and records of all Waqf related issues in Zanzibar as the Act obliged. In order to harmonize this mutual relationship, there is a need to organize regular workshops and training programmes for stakeholders on a regular basis. The training has to discuss on how to plan and construct new Waqf projects including commercial and residential Waqf properties, cash Waqf, plantation and taking share in Islamic economic agencies. 
This will help to adopt more professional attitudes, basic skills in administration and management as well as Shariah rulings while dealing with issues of Waqf projects, trusts, estates of deceased, Hajj (pilgrimage) activities, Zakat and charity.

Another side that needs special attention by the WTC is the community. WTC should organize regular workshops and seminars to the grassroots in order to educate people the importance of using its services. The WTC should improve its services and observe fundamental elements of good governance in order to build confidence of these stakeholders.

Mass media and regular religious forums are needed to share with grassroots experiences concerning the administration and investments of Awqaf, Zakat and charity within Zanzibar, regionally and internationally. The establishment of regular fora which will involve members who should present the Waqf-communities', Hajj groups, Zakat providers, etc. concerning their Waqf properties, which are under the Commission or the activities which are under the coordination of the Commission will strengthen the relationship between WTC and its stakeholders.

In the area of relationship with international organizations and leading countries in administration of the Waqf, the WTC is required to establish relations with other related international agencies and search for networking and technical support from International Islamic Organizations and Muslim countries such as Awqaf South Africa, Ministry of Awqaf of Kuwait, Sudan, Saudi Arabia, Iran and Turkey that will provide experience to WTC Zanzibar. There is a dire need to study current issues on Waqf Asset Management, and Investments from others. Creating partnerships is another alternative of improving WTC. Partnerships are essential for knowledge and skills transfer, for creating connections between organizations and the WTC's working for similar objectives and for bringing diverse skills and resources together to create a synergy for greater impact and achievement.

\section{Inquiry}

2015/1

\section{1}




\section{RECOMMENDATIONS AND CONCLUSION}

This study reviewed the religious duties and responsibilities that are expected by the Government of Zanzibar to be carried out by the Waqf and Property Commission (WTC). It studied the WTC role of taking care of economic growth and reduce poverty in Zanzibar. In doing so, the study provided a clear picture of the WTC; its human, financial and material capacity, the working environment and its relationship with other institutions that have the same responsibilities.

The study found that there are three main challenges that are confronting the administration of WTC, to deliver services that are required. The following are these challenges and potential ways of resolving them:

\begin{tabular}{|c|c|c|}
\hline No. & Challenges & Possible ways of resolving them \\
\hline 1. & $\begin{array}{l}\text { Waqf employees and majority of } \\
\text { the people from the leadership } \\
\text { level to the grass-root lacks prop- } \\
\text { er knowledge of the probate ad- } \\
\text { ministration. Therefore, when one } \\
\text { compares the annual probate cas- } \\
\text { es in Zanzibar and those adminis- } \\
\text { tered by the WTC, one would re- } \\
\text { alize that they are less than } 5 \% \text { of } \\
\text { the potential cases, which poses } \\
\text { a question of the whole issue of } \\
\text { justice in probate administration! }\end{array}$ & $\begin{array}{l}\text { There is a need to organize special- } \\
\text { ized training for administrators, and } \\
\text { to also organize awareness programs } \\
\text { and campaigns at community (She- } \\
\text { hia) level in order to educate the } \\
\text { society on the importance and ad- } \\
\text { vantages of using the WTC services. }\end{array}$ \\
\hline 2. & $\begin{array}{l}\text { In Zanzibar, all land belongs to } \\
\text { the government: This sometimes } \\
\text { leaves the WTC at the crossroads } \\
\text { as the Islamic laws related to Waqf } \\
\text { are considered secondary because } \\
\text { the authority concerning the land } \\
\text { before the bar is the land authority }\end{array}$ & $\begin{array}{l}\text { The WTC should have an authority } \\
\text { over Waqf land; there is an urgent } \\
\text { need to call relevant officials for a } \\
\text { discussion in order to have a com- } \\
\text { mon stand concerning the matter. }\end{array}$ \\
\hline
\end{tabular}




\begin{tabular}{|c|c|c|}
\hline 3. & $\begin{array}{l}\text { Lack of participation of } \\
\text { Zanzibar diasporas that are } \\
\text { scattered worldwide in re- } \\
\text { lations to probate, WTC } \\
\text { administration, Zakat and } \\
\text { charity management, and } \\
\text { pilgrimage coordination }\end{array}$ & $\begin{array}{l}\text { The WTC should be modern- } \\
\text { ized, including establishing a } \\
\text { proper communication sys- } \\
\text { tem, preparing human and } \\
\text { material resources to bene- } \\
\text { fit from the ICT facilities that } \\
\text { would fill the missing link be- } \\
\text { tween the current situation and } \\
\text { potential opportunities. The } \\
\text { result will benefit the coun- } \\
\text { try, whether from within or } \\
\text { from diaspora contributions }\end{array}$ \\
\hline
\end{tabular}




\section{References}

Abdul Sheriff (1995), the Records of the "Waqf Commission" as a source of Social and Religious History of Zanzibar.

Abdulla T. A. (2011), "An Outlook of the Waqf and Trust Commission - Zanzibar".

Anne K. Bang (2002), "Waqf distribution from Zanzibar to Mecca and Medina, ca. 1870-1940, UCLA - CA - USA,

Government of Zanzibar, Act for the establishment of Waqf and Trust Commission

Makaramba V. R. (2004), Review of the functions of the Ministry of State President's office for constitutional Affairs and Good Governance

Mohammed A. M (Ugoda) and Ziddy I. H. (2005) "Research Findings from the Project on Marriage Practices in Zanzibar".

Khalfan M. H. (2009), The State and Potentialities of Waqf in Zanzibar. A paper presented at the Southern Africa Waqf Training Course in Pretoria, South Africa.

Mbarouk M. A. and others (1998), Waqf is it a viable force? NGORC, Zanzibar

Salma Maoulidi (2009) "Between Law and Culture: Reconfiguring Rights for married Women in Zanzibar, IRW Weekly Seminars, The Culture of Rights and the Rights of Culture, Rutgers University".

Ziddy I. H. (2007), Experience and Challenges of the administration of the Waqf institution in Zanzibar, paper presented at the International Conference on Developing Waqf Institutions for sustainable community development and poverty eradication, August 17-19, 2007, Cape Town, South Africa

Zanzibar Government, Several Budget Speeches (2009 - 2012). 


\section{Internet sources:}

http://www.awqaf.net/fatwaa/new-part3/moaam/at/005.html

http://www.manzilat.net/forum/index.php

http://www.islamqa.com/index.php

http://islamweb.net/vers/fatwa/php

http://www.cdhrap.net/text/bohoth/66.htm

http://home.swipnet.se/islam/articles/Non-Muslim-htm

http://www.dailymail.co.uk/news/article-1055764/Islamic-sharia-courts-Britain-legally-binding.html

https://www.zanzibar-paradise.com 
